FIU Law Review

Volume 13

Number 1 Environmental Federalism

Article 10

Summer 2018

\title{
A Bastard by Any Other Name: A Requiem for the End of Disproportionate Treatment Toward Out of Wedlock Children in Florida's Probate System
}

Gregg Strock

Follow this and additional works at: https://ecollections.law.fiu.edu/lawreview

Part of the Family Law Commons, and the State and Local Government Law Commons

Online ISSN: 2643-7759

Recommended Citation

Gregg Strock, A Bastard by Any Other Name: A Requiem for the End of Disproportionate Treatment

Toward Out of Wedlock Children in Florida's Probate System, 13 FIU L. Rev. 127 (2018).

DOI: https://dx.doi.org/10.25148/lawrev.13.1.10

This Student Note is brought to you for free and open access by eCollections. It has been accepted for inclusion in FIU Law Review by an authorized editor of eCollections. For more information, please contact lisdavis@fiu.edu. 


\section{A Bastard by Any Other Name: A Requiem for the END OF DISPROPORTIONATE TREATMENT TOWARD OUT of Wedlock ChILdREN IN FloridA's Probate SySTEM}

Gregg Strock

"There are illegitimate parents, but I don't believe there are any illegitimate children."

-Rick Warren

"Almost in every kingdom the most ancient families have been at first princes' bastards." $\dagger$

-Robert Burton

Introduction

I. Background

A. A Brief History of Paternity Adjudication for Intestate Succession.

B. Other Considerations: Discriminatory Effect; Advanced

Technology

1. Discriminatory Effect

2. Advanced Technology Makes Claiming Paternity Easier Than Ever.

II. Analysis

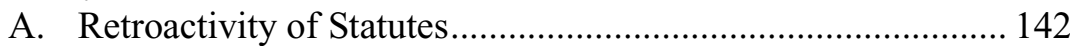

B. Reverse to Revive - Goodbye In re Estate of Smith................ 146

C. Provide A New Claim in Lieu of Reviving the Old One ........ 151

D. Comparative Analysis: Wisdom of Other States May Fill Florida's Legal Void

1. Tennessee 154

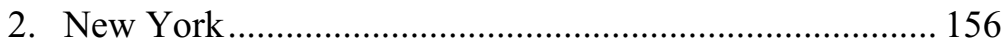

III. Conclusion 158

\footnotetext{
* J.D., 2018, Florida International University College of Law.

$\dagger$ Rick Warren Quotes, BRAINYQUOTE, http://www.brainyquote.com/quotes/quotes/r/rickwarren392313.html.

H Robert Burton Quotes, BRAINYQUOTE, http://www.brainyquote.com/quotes/quotes/r/robertburt403269.html.
} 


\section{INTRODUCTION}

Jon Snow, from the popular HBO fantasy drama, Game of Thrones, may be the most popular bastard of the twenty-first century. ${ }^{1}$ Perhaps sadly, the television show, comparable to the late medieval period in Europe, particularly the fifteenth century, contains notions of illegitimacy that still hold true today. Most notably, "[b]astards are not allowed to inherit their father's lands or titles, and have no claims to the privileges of their father's House." And while the common vernacular has moved away from the word "bastard,"3 children born out of wedlock (also known as nonmarital or illegitimate children) still face an uphill battle when it comes to proving paternity for the purposes of intestate inheritance. ${ }^{4}$ If Snow stated he was under the impression that six centuries later he would be treated as equally as his brothers and sisters, one might reply "you know nothing, Jon Snow."

The statutes and policies concerning rights of children born out of wedlock are ever changing, usually restrictive, inconsistent from state to state, and have historically disadvantaged minority children more than any other group. ${ }^{6}$ The statistical truth is that children of color are far more likely to be born out of wedlock than Caucasian children. ${ }^{7}$ In 1972, the United

1 “I don't care if he's a bastard; Ned Stark's blood runs through his veins. He's my king, from this day until his last day!" Lady Lyanna Mormont, Game of Thrones: The Winds of Winter (HBO television broadcast June 26, 2016). Snow is a prominent point of view character in the novels, and has been called one of the author's "finest creations" and most popular characters by The New York Times. David Orr, Dragons Ascendant: George R. R. Martin and the Rise of Fantasy, N.Y. Times (Aug. 12, 2011).

2 Bastardy, GAME OF THRONES WIKI, http://gameofthrones.wikia.com/wiki/Bastardy (last visited July 1, 2018).

3 Robert A. Brazener, Statute of Limitations in Illegitimacy or Bastardy Proceedings, 59 A.L.R. 3d 685 (1974).

4 John C. Gray, Jr. \& David Rudovsky, The Court Acknowledges the Illegitimate: Levy v. Louisiana and Glona v. American Guarantee \& Liability Insurance Co., 118 U. PA. L. REV. 1 (1969); Solangel Maldonado, Illegitimate Harm: Law, Stigma, and Discrimination Against Nonmarital Children, 63 FLA. L. REV. 345, 347 (2011).

5 Game of Thrones: Sons of the Harpy (HBO television broadcast May 3, 2015).

6 "State laws of succession vary greatly in their treatment of illegitimates, the variance resting in some cases on differences in policy judgments and in others on an apparent legislative unwillingness to initiate changes in an area where pressure for change has not been intense." Note, The Rights of Illegitimates Under Federal Statutes, 76 HARV. L. REV. 337, 337-38 (1962). See generally, Julie E. Goodwin, Not All Children Are Created Equal: A Proposal to Address Equal Protection Inheritance Rights of Posthumously Conceived Children, 4 CONN. PUB. INT. L.J. 234 (2005); Leslie Joan Harris, Reforming Paternity Law to Eliminate Gender, Status, and Class Inequality, 2013 MICH. ST. L. REV. 1295 (2013); States with the Highest Number of Unwed Births, MoM.ME (May 8, 2013) [hereinafter Highest Number of Unwed Births], https://mom.me/kids/7197-us-cities-highest-number-unwedbirths/item/10_168440029/.

7 Louis Jacobson, CNN's Don Lemon Says More Than 72 Percent of African-American Births are out of Wedlock, POLITIFACT (July 29, 2013, 6:48 PM), http://www.politifact.com/truth-ometer/statements/2013/jul/29/don-lemon/cnns-don-lemon-says-more-72-percent-african-americ/; Joyce A. Martin et al., Births: Final Data for 2010, NAT’L Vital Stats. RePS., Aug. 28, 2012, at 45. 
States Supreme Court noted the unfair history of illegitimacy jurisprudence when it said "[t]he status of illegitimacy has expressed through the ages society's condemnation of irresponsible liaisons beyond the bonds of marriage. ... Obviously, no child is responsible for his birth and penalizing the illegitimate child is an ineffectual-as well as an unjust way-of deterring the parent."

In the 1970s, the United States Supreme Court decided a multitude of legitimacy cases, eventually concluding that legitimacy is a classification subject to intermediate scrutiny under the Equal Protection Clause. ${ }^{9}$ In most of these cases, states proposed a rationale of discouraging so called illicit behavior of bearing children out of wedlock. ${ }^{10}$ However, the Supreme Court, at least in early cases regarding wrongful death claims of illegitimate children, found that "state[s] did not demonstrate any nexus between the classifications at issue and their ability to discourage immoral behavior."11 Still, parenthood was and is considered a question of law, ${ }^{12}$ not fact; therefore, as statutes were struck down, they continued to be amended and changed state by state. ${ }^{13}$

Florida is not immune to this history. "The earliest legislation providing a cause of action by which a mother could institute a child-support obligation was called the Bastardy Act, enacted January 5, 1828." ${ }^{14}$ Proceedings under the Bastardy Act were considered quasi-criminal in nature until 1951. ${ }^{15}$ Although the Florida legal system has come a long way from quasi-criminal bastardy proceedings, and the legislature has slowly created access for children to adjudicate paternity, recent developments in the law have created

8 Weber v. Aetna Cas. \& Sur. Co., 406 U.S. 164, 175 (1972).

9 Katharine K. Baker, Legitimate Families and Equal Protection, 56 B.C. L. REV. 1647, 1651 (2015)

10 The State "argued that since the legislature is dealing with 'sin,' it can deal with it selectively and is not compelled to adopt comprehensive or even consistent measures." Glona v. Am. Guarantee \& Liab. Ins., 391 U.S. 73, 75 (1968).

11 Baker, supra note 9, at 1653.

12 Levy v. Louisiana, 391 U.S. 73, 78 (1968).

13 For example, Florida's main paternity statute, $\S 742.01$, has been amended fourteen (14) times since 1951. See FLA. STAT. § 742.01 (2017).

14 Steven Scott Stephens, 23 Florida Family LaW 5:2 (2017).

When any single woman who shall be pregnant or delivered of a child, who by law would be deemed and held a bastard, shall make complaint, to the county judge or the justice of the peace of the district where she may be so pregnant or delivered, and shall accuse any person of being the father of such child, such justice shall issue a process [etc.] ...."

Bishop v. State ex rel. Garnette, 186 So. 413, 414 (Fla. 1939) (quoting FlA. STAT. § 5876 (1927); FLA. STAT. § 3957 (1920)); see also Wall v. Johnson, 78 So. 2d 371, 372 (Fla. 1955). Essentially, the same statute was codified and recodified several times before landing in $\S 742.01$ in 1941. See e.g., Fla. STAT. $\S 742.01$ (repealed 1951); FLA. STAT. § 5876 (1927); FLA. STAT. $\$ 3957$ (1920); FLA. STAT. § 2080 (1892). STEVEN SCOTT STEPHENS, 23 FLORIDA FAMILY LAW 5:2 n.5 (2017).

15 See Steven Scott Stephens, 23 Florida Family LaW 5:2 (2017). 
an insurmountable obstacle to access to the courts for a significant population of the state.

Rose v. Sonson, ${ }^{16}$ holding an amendment to the out of wedlock statute to be only prospective in application, and the statute of limitations it is based upon, creates an inequitable result for a substantial portion of the population of Florida. The case and the statute are, in effect, currently barring a majority of adult children born out of wedlock from establishing paternity for the purposes of intestate succession in probate proceedings if they have reached the age of twenty-two prior to the death of their putative fathers. ${ }^{17}$ This inequitable result requires remedy from the courts and/or the legislature in order to provide equal protection to children born out of wedlock. ${ }^{18}$

The Third District's holding in Rose is too restrictive and will continue to prejudice children born out of wedlock in their ability to access the courts for the purpose of intestate succession for generations to come. ${ }^{19}$ Therefore, Rose should be reversed by the Supreme Court of Florida. In addition, the Florida Legislature needs to correct the statute to expressly provide for retroactive application, or provide a new cause of action to the class of claimants whose claims were extinguished by the former statute of limitations..$^{20}$ Of course, this goal of equal access to the courts for children born out of wedlock must be balanced with the State's legitimate interest in the orderly descent of property, including the need for a well-defined rule, ensuring notice to claimants, protecting the rights of creditors and future owners of the estate's property, avoiding additional restrictions on rights of inheritance than what already exists, and respecting finality in final dispositions. ${ }^{21}$

Most likely, the Florida Supreme Court's hands are tied in its interpretation of the 2009 amendment because of the rule that says an intention to make a statute retroactive must be express on the part of the legislature, which is not the case for this amendment. ${ }^{22}$ Although the legislative history expresses an intention to overrule a case applying the old

16 Rose was the first case interpreting the effect of the 2009 amendment to section $732.108(2)(\mathrm{b})$ of the Florida Statutes. Rose v. Sonson, 208 So. 3d 136 (Fla. Dist. Ct. App. 2016), reh'g denied (Oct. 18, 2016), review denied, SC16-2083, 2017 WL 1954982 (Fla. May 11, 2017).

17 Juan C. Antúnez, 3d DCA: Should We Assume Most Paternity Actions in Probate are Now Time Barred?, Fla. PROB. \& TR. Litig. BloG (Sept. 12, 2016), https://www.flprobatelitigation.com/2016/09/articles/new-probate-cases/practice-procedure/3d-dcashould-we-assume-most-paternity-actions-in-probate-proceedings-are-now-time-barred/.

18 "[T]he Equal Protection Clause necessarily limits the authority of a State to draw such 'legal' lines as it chooses.” Glona v. Am. Guarantee \& Liab. Ins., 391 U.S. 73, 76 (1968).

19 Jacobson, supra note 7.

20 See generally In re Estate of Smith, 685 So. 2d 1206 (Fla. 1996).

21 Bilbrey v. Smithers, 937 S.W.2d 803, 808 (Tenn. 1996).

22 See Fitchner v. Lifesouth Cmty. Blood Ctrs., Inc., 88 So. $3 d 269$ (Fla. Dist. Ct. App. 2012). 
statute of limitations, neither the face of the statute nor its legislative history contain an express intention to apply the statute retroactively. ${ }^{23}$

There may be another approach to the same result that retroactive application would have- that is, overruling the case currently on the books that applied the statute of limitations in the first place which currently contradicts the intention of the 2009 amendment. By overruling the case mentioned in the legislative history, ${ }^{24}$ the Florida Supreme Court could remove the statute of limitations without having to apply the amendment retroactively. Both the Florida Legislature and the Florida Supreme Court should act to fix the inequitable results of the 2009 amendment to, and previous holdings interpreting, section 732.108(2)(b) of the Florida Statutes. The legislature can provide a new cause of action, and the Court can overrule its decision that applied the controversial statute of limitations in the 1990s.

In regard to this pressing issue, this Comment will first discuss the history of paternity adjudications in Florida probate court, consider the historical discriminatory effects of legitimacy statutes, and consider what effect technological advances in DNA testing should have on legitimacy policy. Next, this Comment will analyze the Third District's holding in Rose $v$. Sonson, analyze the rules of construction regarding retroactivity of statutes in Florida, compare the holding and statutes to other states' policies on time limits to adjudicating paternity, and finally, provide suggestions to make the rules less restrictive and more equitable.

\section{BACKGROUND}

\section{A. A Brief History of Paternity Adjudication for Intestate Succession}

At common law, rules governing inheritance by children born out of wedlock were archaic, referring to the children as bastards for "bastardy" proceedings. ${ }^{25}$ Children born out of wedlock had little to no rights because most states followed the common law rule of nullius filius. ${ }^{26}$ Under nullius filius, a child born out of wedlock was considered the child of no one. ${ }^{27}$ Therefore, the child was considered to lack "heritable blood," and was unable to inherit from either natural parent. ${ }^{28}$ Under the common law, putative (2009)

23 Fla. H.R. Comm. On Civil Justice \& Courts Policy, Staff Analysis of HB 599, at 1, 3

24 Smith, 685 So. 2 d at 1206.

25 E.W.H., Annotation, Inheritance by, from, or Through Illegitimate, 83 A.L.R. 1330 (1933).

26 See generally Metro. Life Ins. v. Thompson, 368 F.2d 791, 794 (3d Cir. 1966); In re Caldwell's Estate, 247 So. 2d 1, 5 (Fla. 1971) (Ervin, J., dissenting); In re Estate of Ellis, 225 Iowa 1279, 1288 (1939).

27 Caldwell, 247 So. 2 d at 5 (Ervin, J., dissenting).

28 Allen v. Harvey, 568 S.W.2d 829, 831 (Tenn. 1978). 
fathers had no duty or rights related to their children born out of wedlock. ${ }^{29}$ It was "generally recognized that in the absence of any statute conferring rights of inheritance upon them, illegitimate children [were] without capacity to inherit from or through either parent." ${ }^{30}$ Eventually, children born out of wedlock were held to be protected by equal protection guarantees in regard to benefits under the Social Security Act and access to support from putative fathers. ${ }^{31}$ However, inheritance remained a right that could only be granted, and subject to repeal, by statute. ${ }^{32}$

Florida courts began recognizing children born out of wedlock with the Bastardy Act in $1828 .{ }^{33}$ The act was a child-support law, quasi-criminal in nature. ${ }^{34}$ This law only applied to children born in Florida, and provided no right to inherit for a child born out of wedlock. ${ }^{35}$ The state first allowed nonmarital children to inherit from a parent as the natural kindred of the mother in $1927 .{ }^{36}$ In 1933, under section 30 of the Probate Act, Florida started allowing an illegitimate child to inherit from the father when the father provided written acknowledgement of paternity. ${ }^{37}$ Then, in 1978, in In re Burris Estate, former section 731.29 of the Florida Statutes (successor statute of section 30) was held to be "in violation of the equal protection clauses of the state and federal constitutions" because the statutory differentiation of children on the basis of illegitimacy was not justified by recognized state objectives. ${ }^{38}$

29 Ford v. Loeffler, 363 So. 2d 23, 24 (Fla. Dist. Ct. App. 1978).

30 Caldwell, 247 So. 2 d at 5 (Ervin, J., dissenting).

31 See Levy v. Louisiana, 391 U.S. 68, 70-71 (1968).

32 See generally Note, The Rights of Illegitimates Under Federal Statutes, 76 HARV. L. REV. 337 (1962).

33 See Ex parte Hays, 6 So. 64 (Fla. 1889).

34 The alleged father was arrested, bonded, arraigned, and held for jury trial. See Bishop v. State ex rel. Garnette, 186 So. 413, 413-14 (Fla. 1939); Ex parte Hayes, 6 So. 64, 64 (Fla. 1889). The quasicriminal nature of bastardy proceedings was still in effect in 1930. State v. Rowe, 128 So. 7, 8 (Fla. 1930); Stephens, supra note 14, at $\S 5: 2$ n.2.

35 Campbell v. State, 59 So. 893, 893-94 (Fla. 1912).

36 In re Estate of Horne, 7 So. 2d 13, 15 (Fla. 1942).

37 Id. at 13; Florida Statutes $\S 731.29(1)$ mirrored the 1933 statute, providing that an illegitimate child is an heir:

Every illegitimate child is an heir of his mother, and also of the person who, in writing, signed in the presence of a competent witness, acknowledges himself to be the father. Such illegitimate child shall inherit from his mother and also, when so recognized, from his father, in the same manner as if the child had been born in lawful wedlock. However, such illegitimate child does not represent his father or mother by inheriting any part of the estate of the parents' kindred, either lineal or collateral, unless his parents have intermarried, in which event such illegitimate child shall be deemed legitimate for all purposes.

FLA. STAT. § 731.29(1) (repealed 1974).

38 In re Burris Estate, 361 So. 2d 152, 152, 154 (Fla. 1978). 
In In re Burris Estate, four children born out of wedlock claimed a right to shares of the decedent's estate, despite failing to meet the statutory requirement of paternity being acknowledged in writing by the putative father while he was living. ${ }^{39}$ The trial court completed a full factual inquiry and found that the claimants were the natural children of the decedent. ${ }^{40}$ Given the circumstances of the case, the "trial court held that section 731.29(1), Florida Statutes (1973) was unconstitutional, in violation of the equal protection clauses of the state and federal constitutions." 41 The trial court recognized a clear interest of the state in the orderly descent of the property of its citizens, but found that such an interest did not justify the differentiation based on illegitimacy. ${ }^{42}$ "Therefore, the trial court concluded that the four illegitimate children should share equally in the estate with the three legitimate children of the deceased." 43

On appeal, the Florida Supreme Court affirmed. ${ }^{44}$ In its opinion, the Court questioned whether denying a child born out of wedlock the right to inherit from his father could be constitutional. ${ }^{45}$ To answer the question, the Court adopted the test "as expressed by the United States Supreme Court in Trimble ... an analysis of whether the statutory differentiation on the basis of illegitimacy is justified by the promotion of recognized state objectives." ${ }^{46}$ Applying this test, the court noted that the state's interest in the orderly descent of property could justify a higher degree of proof for paternity than maternity. ${ }^{47}$

However, the Court held that section 731.29(1) did not address "standard of proof," but rather limited what kind of evidence could be used to meet the heightened standard. ${ }^{48}$ The Court found that "[e]ven proof beyond a reasonable doubt would be insufficient unless the illegitimate child introduced evidence of a written acknowledgement, signed by the natural father in the presence of a competent witness." ${ }^{49}$ Such a statute did not serve the state's interest, but instead created an "impenetrable barrier that works to shield invidious discrimination." ${ }^{50}$ Based on the foregoing, the Court held

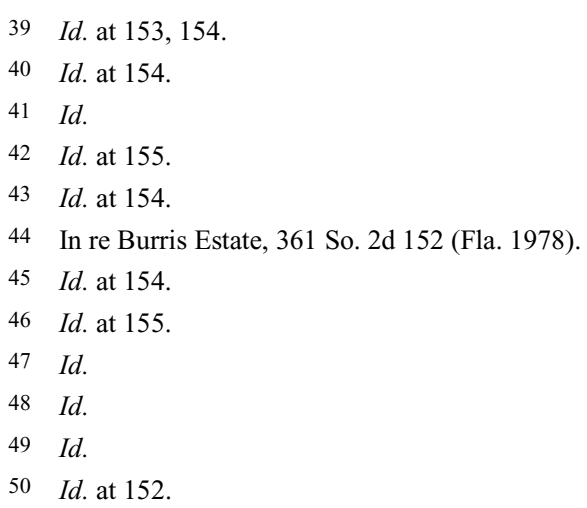


that "no sufficient reason ha[d] been asserted to justify th[e] . . restrictions on an illegitimate's right to inherit intestate property," and affirmed the trial court's ruling of unconstitutionality. ${ }^{51}$

Before In re Estate of Burris was decided by the Supreme Court, section 731.29 was replaced by section 732.108 , which took effect on January 1 , 1976, and allowed "an illegitimate child to take an intestate share if the paternity of the child is adjudicated, either before or after the death of the father." ${ }^{52}$ Although this new right to adjudicate paternity after the death of the putative father was a great leap forward for children born out of wedlock, the statute still had problems. For example, until October 1986, "only the mother of a child born out of wedlock could bring suit to establish paternity." ${ }^{33}$ Putative children and fathers were unable to bring paternity actions until section 742.011, amended in 1986, allowed the previously barred parties to bring paternity actions. ${ }^{54}$

The access to the courts that the amendment to section 742.011 created was then severely limited by the Florida Supreme Court in In re Estate of Smith. ${ }^{55}$ There, the court applied section 95.11(3)(b), thus imposing a fouryear statute of limitations for paternity actions in probate proceedings, beginning from the date that the putative child turned eighteen. ${ }^{56}$ In Smith, a sixty-year-old brought a paternity action in probate court to assert her right to intestate succession..$^{57}$ The Court rejected the lower court's holding "that section 732.108(2)(b) creates a separate and distinct statutory cause of action [for determining paternity in probate courts] which begins to run upon the death of the putative father rather than when the child reaches the age of majority." ${ }^{58}$ Smith was denied the right to have her paternity adjudicated, as was every other citizen of Florida who had reached the age of twenty-two, even if the putative father had not yet died. ${ }^{59}$ Thus, the statute of limitations was, in essence, a statute of repose, allowing a claim to extinguish before it ever accrued upon the death of the putative father. ${ }^{60}$

$51 \quad I d$.

52 Id. at 155-56; FLA. STAT. § 732.108 (1977).

53 Rose v. Sonson, 208 So. 3d 136 (Fla. Dist. Ct. App. 2016), reh'g denied (Oct. 18, 2016), review denied, SC16-2083, 2017 WL 1954982 (Fla. May 11, 2017); see FLA. STAT. § 742.011 (1981).

54 Rose, 208 So. 3d at 136, 138.

55 In re Estate of Smith, 685 So. 2d 1206, 1208 (Fla. 1996).

$56 I d$. at 1210; "Actions other than for recovery of real property shall be commenced as follows: (3) Within four years.- (b) An action relating to the determination of paternity, with the time running from the date the child reaches the age of majority ...." FLA. STAT. § 95.11(3)(b) (1996).

57 Smith, 685 So. $2 \mathrm{~d}$ at 1207.

58 Rose, 208 So. 3d at 138 (quoting Smith, 685 So. 2d at 1208).

59 Smith, 685 So. $2 \mathrm{~d}$ at 1210.

60 "A statute barring any suit that is brought after a specified time since the defendant acted (such as by designing or manufacturing a product), even if this period ends before the plaintiff has suffered a 
In 2009, an amendment to section 732.108(2)(b) was passed expressly stating that section 95.11(3)(b) (and Chapter 95 as a whole) "shall not" apply to paternity actions in probate court. ${ }^{61}$ The Florida Staff Analysis further states that "[t]his bill overrules the holding in Estate v. Smith." ${ }^{\prime 2}$ However, neither the amended statute nor the legislative history made express mention of the retroactivity of the amendment or the overruling of Smith. ${ }^{63}$ On September 7, 2016, Florida's Third District Court of Appeal took up the issue of retroactivity of the 2009 amendment in Rose v. Sonson. ${ }^{64}$

Stephen C. Rose was born out of wedlock on December 25, $1964 .{ }^{65}$ Stephen's mother never tried to prove paternity during Rose's childhood under section 742.011 of the Florida Statutes. ${ }^{66}$ In 1986, section 742.011 was amended, allowing both putative children and putative fathers to bring paternity actions. ${ }^{67}$ However, section $95.11(3)(b)$ of the Florida Statutes also applied, imposing a four-year statute of limitations beginning on the date the child reaches the age of majority. Rose did not bring his claim within the little time he had left. ${ }^{68}$ Rose's father, Stephen Sonson, died intestate on June 21, 2012. ${ }^{69}$ Rose filed a counter-petition in probate court "claiming to be a surviving son of the decedent and therefore a rightful beneficiary of the estate." 70 The trial court dismissed the counter petition, holding that:

resulting injury ... " Statute of Repose, BLACK's LAW DiCTIONARY (10th ed. 2014); see also 54 C.J.S. Limitations of Actions $\S 47$ (2017) ("A statute of repose ... limits the time within which an action may be brought and is not related to the accrual of any cause of action; the injury need not have occurred, much less have been discovered. Unlike an ordinary statute of limitations which begins running upon accrual of the claim, the period contained in a statute of repose begins when a specific event occurs, regardless of whether a cause of action has accrued or whether any injury has resulted.").

61 "The paternity of the father is established by an adjudication before or after the death of the father. Chapter 95 shall not apply in determining heirs in a probate proceeding under this paragraph." FLA. STAT. § 732.108(2)(b) (2009).
62 H.B. 599, 2009 H.R. Reg. Sess. (Fla. 2009).
63 House Bill 599 provides:

This bill overrules the holding in Estate v. Smith and provides that ch. 95, F.S., does not apply in determining heirs in a probate proceeding. Therefore, this bill allows for a determination of paternity to be made in a probate proceeding for the purpose of proving heirship, even if it is more than four years after the date the child reaches majority. This change is limited to intestate succession. Id.

64 Rose v. Sonson, 208 So. 3d 136 (Fla. Dist. Ct. App. 2016), reh'g denied (Oct. 18, 2016), review denied, SC16-2083, 2017 WL 1954982 (Fla. May 11, 2017).
65 Id.
67 Rose, 208 So. 3d at 138.
68 Id.
69 Id.
70 Id. at 137.

66 Id. at 137; see FLA. STAT. § 742.011 (1981) ("Any woman who shall be pregnant or delivered of a child may bring proceedings in the circuit court, in chancery, to determine the paternity of such child."). 
(1) the 2009 amendment to section 732.108(2)(b) of the Florida Statutes, which eliminated the four year statute of limitations previously applicable to paternity determinations, could not revive Rose's already extinguished claim; (2) that the 2009 amendment to section 732.108(2)(b) did not apply retroactively because the Florida Legislature did not express a clear intent it was to be so applied; and (3) that any such retroactive application would constitute a violation of the decedent's and of the copersonal representatives' due process rights because Rose's claim was already extinguished. ${ }^{71}$

On appeal, the Third District Court of Appeal affirmed the holdings of the trial court, vastly restricting the application of the 2009 amendment to section $732.108 .^{72}$ If a person was twenty-two years or older in 2009 , or twenty-nine when Rose was decided, then that person is now legally unable to adjudicate paternity in a Florida probate proceeding - which represents about sixty-five percent of Florida's current population. ${ }^{73}$ So, while the 2009 amendment removing the four-year statute of limitations for paternity actions in probate proceedings will certainly help Florida put its history of bastardy proceedings and unfair treatment regarding the rights of children born out of wedlock behind it, such a change may take multiple decades to truly have an effect because of the amendment's failure to apply retroactively.

Finally, the law is currently unclear on the time limitations, if any, that a person who was twenty-one or younger in 2009 has to file a paternity action in probate court. A fair and reasonable time limitation can be established so that the rights of children born out of wedlock can be balanced with the state's interest in the orderly and timely descent of the property of its citizens. The out of wedlock statute must serve the state's interest without creating an "impenetrable barrier that works to shield invidious discrimination."

73 Office of Econ. \& Demographic Research, Percentage by Age Group: Florida 4 (2015), http://edr.state.fl.us/Content/population-demographics/data/Pop_Census_Day.pdf; Antúnez, supra note 17.

74 In re Burris Estate, 361 So. 2d 152, 155 (Fla. 1978) (quoting Trimble v. Gordon, 430 U.S. 762, 771 (1977)). 


\section{B. Other Considerations: Discriminatory Effect; Advanced Technology}

\section{Discriminatory Effect}

Although this Comment will not cover all the realms of important and interesting topics that one could consider when assessing the laws that govern inheritance rights of children born out of wedlock, it would be a disservice not to mention the historical discriminatory effect that these laws have had. Just as race has shaped so many areas of American society and law, family law and inheritance in Florida and in the United States has not evolved in a vacuum and has been affected by this history too.

Minorities, specifically African-Americans, are the group of people most impacted by restrictive laws related to paternity adjudication in probate court. ${ }^{75}$ More than seventy-two percent of children in the African-American communities are born out of wedlock. ${ }^{76}$ Almost every other minority group is above twenty-five percent. ${ }^{77}$ Further, Florida is one of the states with the most births out of wedlock in the United States, with 206,786 nonmarital births in Florida in 2011 - forty percent of all births that year. ${ }^{78}$ Inevitably, minorities will be discriminated against by the Rose holding.

Perhaps, not so inadvertently, society has cast a false lens upon fathers of illegitimate children in minority communities. ${ }^{79}$ Although minority fathers of children born out of wedlock are often keenly involved in raising their children, the stereotype of the absent African-American (and minority) father continues to be prevalent throughout modern society. ${ }^{80}$ Sadly, "[f]or decades, government officials have focused on paternal absence in African-American families, treating '[f]atherlessness ... as a distinctly Black problem,' and blaming absent fathers for many of the social ills plaguing African-American communities - poverty, teen pregnancy, high delinquency and incarceration

75 Professor Harry Krause, who advocated for the rights of nonmarital children, argued that laws discriminating against nonmarital children disproportionately impacted African-American children. Harry D. Krause, Illegitimacy: Law AND Social Policy 259-60 (1971) (noting that 95.8\% of persons impacted by the statute at issue in Levy v. Louisiana were African-American).

76 Jacobson, supra note 7.

77 Id.

78 Highest Number of Unwed Births, supra note 6.

79 "American public's image of a nonmarital child was that of an African-American child with a welfare-dependent mother and an absent father." Solangel Maldonado, Illegitimate Harm: Law, Stigma, and Discrimination Against Nonmarital Children, 63 FLA. L. REV. 345, 367-68 (2011).

80 See Dorothy Roberts, The Absent Black Father, in LOST FATHERS: THE Politics of FATHERLESSNESS IN AMERICA 145-146 (Cynthia R. Daniels ed., 1998). 
rates, poor academic performance, and idleness." ${ }^{81}$ This racially charged history has created a system that punishes children for the so-called "sins" of their fathers. Lack of empathy for the father has no doubt translated to a lack of empathy for the child born out of wedlock. ${ }^{82}$ Society's condemnation of the untraditional family has ended up harming the most innocent members of society-children. ${ }^{83}$

One also must not overlook the great diversity that makes up nonmarital children, because assuming that only poor, minority mothers and poor, absent, minority fathers bear the majority of children out of wedlock would be a grave mistake:

More than $50 \%$ of all nonmarital children today are born to cohabiting couples, $15 \%$ of which marry within a year of the child's birth. Another 14\% are born to divorced women, some of which have children from a previous marriage, and $22 \%$ are born to teenage mothers. While many nonmarital children are born to low-income women, many others are born to financially successful women. Nonmarital birth rates also vary by race and ethnicity. Twenty-nine percent of children born to white women in 2008 were nonmarital, as were $53 \%$ of children born to Latinas, and $72 \%$ of children born to African-American women. ${ }^{84}$

Future students, scholars, members of the Florida Legislature, judges, and justices should not ignore these statistics and this history in their future endeavors when analyzing and shaping the out of wedlock laws. No matter society's current or future beliefs about parents having children out of wedlock, those beliefs should not impose punishment upon childrenespecially the historically disadvantaged - who are wholly innocent of their parents' acts. As the Supreme Court said, "no child is responsible for his birth

81 Solangel Maldonado, Deadbeat or Deadbroke: Redefining Child Support for Poor Fathers, 39 U.C. DAVIS L. REV. 991, 993-94 (2006).

82 See Weber v. Aetna Cas. \& Sur. Co., 406 U.S. 164, 175 (1972) ("The status of illegitimacy has expressed through the ages society's condemnation of irresponsible liaisons beyond the bonds of marriage.”); Levy v. Louisiana, 391 U.S. 68, 70 (1968) (quoting Levy v. State, 192 So. 2d 193, 195 (La. Ct. App. 1967) ("Denying illegitimate children the right to recover in such a case is actually based on morals and general welfare because it discourages bringing children into the world out of wedlock.")).

83 Traditionally, children who were conceived or born out of lawful wedlock were considered illegitimate even if their parents later married. See John Witte, Jr., Ishmael's Bane: The Sin and Crime of Illegitimacy Reconsidered, 5 PUNISHMENT \& SOC'Y 327, 334 (2003).

84 Solangel Maldonado, Illegitimate Harm: Law, Stigma, and Discrimination Against Nonmarital Children, 63 FLA. L. REV. 345, 369 (2011). 
and penalizing the illegitimate child is an ineffectual as well as an unjust way of deterring the parent." 85

\section{Advanced Technology Makes Claiming Paternity Easier Than Ever}

Although technology has made it easier than ever to prove paternity, one must still balance this fact with the interest of distributing property in a timely manner, and the unlikeliness and expense of getting DNA after burial. A forever claim is not realistic, but there are more equitable timeframes for the statute of limitations, based on availability of DNA evidence, that can be implemented in Florida.

Before technology advanced to allow humans to test parentage by scientific means, there existed the maxim mater semper certa est pater semper incertus est, which translates as "mother is always certain, and father is always uncertain." 86 Today's technology has completely changed the method and accuracy of how parentage is proven, almost to the point of certainty:

The current state of paternity testing technology offers an accurate, efficient, and relatively inexpensive means of establishing paternity. DNA testing may be conducted on relatively small samples of blood or cells. Tests kits marketed to consumers are readily available online and in local pharmacies at diverse price ranges. These at-home kits typically utilize a buccal swab to collect cheek cells from inside of the mouth. However, DNA collection need not be restricted to blood samples and cheek cells. DNA also can be extracted from hair and other biological material, with or without the donor's consent or knowledge. The collected cells are then sent to a laboratory for test results. Thus, the current genetic tests are less expensive, less invasive, and yield more accurate results. ${ }^{87}$

85 Weber, 406 U.S. at 175 . For those wishing to explore the issue of discrimination against minority children born out of wedlock further, there are various articles that cover the issue in depth. See, e.g., Julie E. Goodwin, Not All Children Are Created Equal: A Proposal to Address Equal Protection Inheritance Rights of Posthumously Conceived Children, 4 CONN. PUB. INT. L.J. 234 (2005); Leslie Joan Harris, Reforming Paternity Law to Eliminate Gender, Status, and Class Inequality, 2013 MiCH. ST. L. REV. 1295 (2013); Solangel Maldonado, Illegitimate Harm: Law, Stigma, and Discrimination Against Nonmarital Children, 63 FLA. L. REV. 345, 366-68 (2011).

86 Vanessa S. Browne-Barbour, “Mama's Baby, Papa's Maybe:” Disestablishment of Paternity, 48 AKRON L. REV. 263, 267 (2015).

87 Id. at 303-04. 
"[I]n In re Estate of Bonanno, the court held that posthumous genetic test results could be admitted to satisfy the clear and convincing evidence requirement of $4-1.2(\mathrm{a})(2)(\mathrm{C})$ in order to prove paternity in heirship claims." ${ }^{88}$ While the technology is available, procedural difficulties still remain. ${ }^{89}$ For example, at what point does privacy and respect for the remains of the deceased become an issue? One day after death? After burial? ${ }^{90}$

In Wingate v. Estate of Ryan, the Supreme Court of New Jersey had to decide whether to allow a DNA test to be completed after the death of the putative father. ${ }^{91}$ The plaintiff, Joanne Wingate, grew up believing that her father was Willard Wingate. ${ }^{92}$ In fact, the plaintiff's father was John L. Ryan (the decedent in the case), a close family friend. ${ }^{93}$ Just ten days before the death of Ryan, the mother disclosed the truth to Wingate. ${ }^{94}$ "The day after Ryan's death, Joanne filed a claim under the Probate Code to establish that she was an heir to Ryan's intestate estate," and "obtained a court order permitting a DNA test on blood and hair samples taken from Ryan before embalming. The tests confirmed that Ryan was her biological father." 95

Wingate is a straightforward example of using DNA testing technology after death, because the decedent's body was available to be tested prior to embalming or burial. ${ }^{96}$ But what about disturbing the body or remains at a time further removed from the date of death? Other countries have adopted the practice, but there is no doubt that such a policy would need to be

88 In re Bonanno, 745 N.Y.S. 2d 813, 815 (N.Y. Sur. Ct. 2002); Megan Pandelton, Intestate Inheritance Claim: Determining A Child's Right to Inherit When Biological and Presumptive Paternity Overlap, 29 CARDOZO L. REV. 2823, 2855 (2008). The Bonanno court noted that, despite the requirement that genetic testing be administered during a putative father's lifetime under EPTL 4-1.2 (a)(2)(D), "[t]here is no basis in law or logic to exclude the results of posthumously conducted DNA tests on a decedent's genetic material from the category of 'clear and convincing' evidence under EPTL 4-1.2 (a)(2)(C)." Bonanno, 745 N.Y.S. $2 \mathrm{~d}$ at 815.

89 See In re Davis, 812 N.Y.S. 2d 543, 546 (N.Y. App. Div. 2006).

90 This comment will not provide an opinion on the practice of disturbing the remains of a putative father to establish paternity for the purposes of intestate succession, although it is not unheard of.

91 Wingate v. Estate of Ryan, 693 A.2d 457, 458-59 (N.J. 1997).

92 Id. at 459.

93 Disclosure of the relationship was embarrassing to the family:

According to Parsio [the mother], decedent acknowledged to her that he was plaintiff's biological father on several occasions, but decedent repeatedly refused to publicly acknowledge that fact because he and Parsio were not married, and such a revelation would cause embarrassment, particularly in light of his Catholic faith. Parsio claims that she did not reveal decedent's paternity because Ryan threatened to "cut off ties," including financial support, to her and plaintiff.

Id.

94 Id.

95 Wingate, 693 A.2d at 459; Megan Pendleton, Intestate Inheritance Claims: Determining A Child's Right to Inherit When Biological and Presumptive Paternity Overlap, 29 CARDOZO L. REV. 2823, 2846 n.151 (2008).

96 Wingate, 693 A.2d at 459. 
balanced with the interest of privacy. ${ }^{97}$ In the case of Jäggi v. Switzerland, the European Court of Human Rights (ECHR) had to consider whether the remains of a putative father could be disturbed nearly thirty years after his death, where the "child" was sixty-seven years old at the time of the ECHR's judgment. ${ }^{98}$ One can infer that the ECHR's decision in favor of the applicant was an affirmation of the practice of DNA testing, well after the death of a putative father, depending on the factual circumstances. ${ }^{99}$

In Jäggi, the ECHR noted:

[People] seeking to establish the identity of their ascendants have a vital interest ... in receiving the information necessary to uncover the truth ... At the same time ... protection of third persons may preclude their being compelled ... for medical testing of any kind .... ${ }^{100}$ "[C]onsideration should be given ... to the applicant's right to establish his parentage and ... to the right of third parties to the inviolability of the deceased's body, the right to respect for the dead, and the public interest in preserving legal certainty." 101

Ultimately, the ECHR awarded damages to the applicant from the state for violating the applicant's rights by refusing DNA testing over a period of nearly thirty years. ${ }^{102}$

The Convention for the Protection of Human Rights and Fundamental Freedoms, an international treaty, and the Florida statutes regarding intestate inheritance for children born out of wedlock are two very different beasts. Nonetheless, when it comes to proving paternity with DNA, genetic testing is too advanced to not consider its implications upon the issues addressed here. Both children claiming the right to inheritance and decedent estates have rights that must be balanced, and examples from other jurisdictions (both domestic and international) can help to bridge the gap in this area of law. Scientific advancements have made it so that a strict statute of limitations may no longer make sense when justified by an interest in

97 See Jäggi v. Switzerland, App. No. 58757/00, Eur. Ct. H.R. at 3-5 (2006), https://hudoc.echr.coe.int/app/conversion/pdf/?library=ECHR\&id=003-1736071-

1820318\&filename=003-1736071-1820318.pdf; Kroon v. Netherlands, App. No. 18535/91, Eur. Ct. H.R. at 4-5 (1994), http://hudoc.echr.coe.int/sites/eng/pages/search.aspx?i=001-57904.

98 Jäggi v. Switzerland, App. No. 58757/00, Eur. Ct. H.R. at 3 (2006), https://hudoc.echr.coe.int/app/conversion/pdf/?library=ECHR\&id=003-17360711820318\&filename $=003-1736071-1820318$.pdf.

99 Id. at 7.

100 Id

$101 I d$.

102 Id. at 9-10. 
certainty of parentage. Certainty can be achieved many years after death, other considerations aside.

\section{ANAlysis}

The Florida Legislature and/or Florida Supreme Court must provide a means for claimants like Stephen Rose, who were older than twenty-two in 2009, an opportunity to claim their right to inherit after their father has died. For those whose fathers have long passed with estates administered, the state's interest in finality and the orderly descent of property is too strong to justify opening a closed probate administration. However, where administration has not begun, and a father is still living, it would be unfair to deny a child born out of wedlock his or her right to access to the courts. It seems there are three possible ways to provide for this intended purpose: (1) for the Florida Legislature to amend the 2009 statute to include an express intention of retroactivity; (2) for the Florida Supreme Court to expressly overrule its holding in In re Estate of Smith (applying the statute of limitations), instead adopting the First District Court of Appeal's opinion; or (3) for the Florida Legislature to amend section 732.108(2)(b) to provide a new cause of action for claimants similarly situated to Rose- provide a new claim rather than revive the old one.

\section{A. Retroactivity of Statutes}

One of the three holdings of Rose v. Sonson was that "the 2009 amendment to section 732.108(2)(b) did not apply retroactively because the Florida Legislature did not express a clear intent it was to be so applied." ${ }^{\prime 103}$ In Florida, for a statute to be applied retroactively, "the Legislature must have expressed its intention to apply the law retroactively in language that is "too clear and explicit to admit of reasonable doubt."'104 One important reason for this requirement of an express intention is the need for checks and balances, and the policy against the judiciary infringing upon the legislature by creating law. ${ }^{105}$ There is a distinction between a substantive statute and a procedural

103 Rose v. Sonson, 208 So. 3d 136 (Fla. Dist. Ct. App. 2016), reh'g denied (Oct. 18, 2016), review denied, SC16-2083, 2017 WL 1954982 (Fla. May 11, 2017).

104 Fitchner v. Lifesouth Cmty. Blood Ctrs., Inc., 88 So. 3d 269 (Fla. Dist. Ct. App. 2012) (quoting Trs. of Tufts Coll. v. Triple R. Ranch, Inc., 275 So. 2d 521, 524 (Fla. 1973)); see also Basel v. McFarland \& Sons, Inc., 815 So. 2d 687, 692-93 (Fla. Dist. Ct. App. 2002); Metro. Dade Cty. v. Chase Fed. Hous. Corp., 737 So. 2d 494, 499 (Fla. 1999).

105 In Fleeman v. Case, the Florida Supreme Court stated:

[I] $\mathrm{f}$ we insist that a declaration of retroactive application be made expressly in the legislation under review[,] . . . the forward or backward reach of proposed laws is irrevocably assigned in the forum best suited to determine that issue, and the judiciary is limited only to determining in appropriate 
or remedial statute, so that "[t]he general rule is that a substantive statute will not operate retrospectively absent clear legislative intent to the contrary but that a procedural or remedial statute is to operate retrospectively and should be applied to pending cases in order to fully effectuate the Legislation's intended purpose." 106

Although, in Rose, the Third District Court of Appeal treated the amendment as a substantive statute because it considers heirs to have a vested interest in the estate of the decedent, it can be argued that the amendment to section 732.108(2)(b) is actually remedial or procedural. "Remedial statutes operate to further a remedy or confirm rights that already exist, and a procedural law provides the means and methods for the application and enforcement of existing duties and rights." 107 The amendment at issue does not create or take away a right, it simply confirms that right by removing an unconstitutional bar to asserting the right - the statute of limitations that allows claims to be lost before they ever accrue. ${ }^{108}$

Difficulty arises even if accepting the amendment as procedural or remedial because a statute of limitations does provide a defense for a defendant to assert, providing finality and predictability to the defendant. ${ }^{109}$ That defense may be considered a right in and of itself. Therefore, the amendment may be "an act designed to serve a remedial purpose," but cannot be applied retroactively because "it is clear that doing so would attach new legal consequences to events completed before its enactment." the amendment retroactively poses many challenges, including this substantive versus remedial/procedural issue, as well as the legislature's failure to address the need for an express intention of retroactivity within the face of the statute. ${ }^{111}$

cases whether the expressed retroactive application of the law collides with any overriding constitutional provision.

342 So. 2d 815, 817-18 (Fla. 1976).

106 JOHN J. DVORSKE ET AL., 48A FLORIDA JURISPRUDENCE $§ 107$ (2d. ed. 2017).

107 Id.

108 In re Estate of Smith, 685 So. 2d 1206 (Fla. 1996); see also FLA. STAT. § 95.11(3)(b) (2017), providing: "Actions other than for recovery of real property shall be commenced as follows: (3) Within four years ... (b) An action relating to the determination of paternity, with the time running from the date the child reaches the age of majority."

109 "The statute of limitations is a defense that is ordinarily asserted by the defendant to defeat an action brought against him after the appropriate time has elapsed." Statute of Limitations, LEGALDICTIONARY, http://legal-dictionary.thefreedictionary.com/statute+of+limitations.

110 DvORSKE ET AL., supra note 106; see also Morris v. Swanson, 940 So. 2d 1256 (Fla. Dist. Ct. App. 2006).

111 "Florida legislation is presumed to operate prospectively unless there exists a showing on the face of the law that retroactive application is intended." DVORSKE ET AL., supra note $106 \S 106$; see also Yamaha Parts Distribs. Inc. v. Ehrman, 316 So. 2d 557 (Fla. 1975). 
Even if the legislature had shown an express intention of retroactivity within the statute, a retroactive statute cannot "breathe new life into [a] previously extinguished claim." 112 The problem that Rose (and other similar cases) poses to retroactive application of the 2009 amendment is that "retroactive application would constitute a violation of the decedent's and of the [personal] representatives' due process rights because Rose's claim was already extinguished." 113 "Once the defense of the statute of limitations has accrued, it is protected as a property interest just as the plaintiff's right to commence an action is a valid and protected property interest." "Statutes that relate only to procedure or remedy generally apply to all pending cases, but a substantive law that interferes with vested rights will not be applied retrospectively." 115

However, the question must be posed - are the rights truly vested if they were based on an unconstitutional application of a statute of limitations? And, does the due process concern of the so-called "vested rights" of the decedent and personal representative trump the due process and equal protection concerns that arise from extinguishing the illegitimate child's access to court before his or her claim has accrued? ${ }^{116}$ To answer this question, one may look to the wisdom of another jurisdiction with substantially similar rules.

In 1981, the Court of Appeal of Tennessee, in Thompson v. Coates, dealt with a similar statute to Florida's section $732.108(2)(b) .{ }^{117}$ Like section 732.108(2)(b) of the Florida Statutes, Tennessee's statute allows for adjudication to be proven after the death of the putative father. ${ }^{118}$ In Thompson, an action was instituted to establish that the plaintiff was the illegitimate child of the individual whose estate the defendant was administering. ${ }^{119}$ The defendants argued, inter alia, that the plaintiff was barred from making a claim to inheritance because the property right had

112 Rose v. Sonson, 208 So. 3d 136 (Fla. Dist. Ct. App. 2016), reh'g denied (Oct. 18, 2016), review denied, SC16-2083, 2017 WL 1954982 (Fla. May 11, 2017).

113 Id.

114 Wiley v. Roof, 641 So. 2d 66, 68 (Fla.1994).

115 Morris, 940 So. 2d at 1256.

116 See Baker, supra note 9, at 1681 ("Intestacy statutes, by their nature, implicate the two strands of equal protection - fundamental rights and suspect classification - that trigger judicial scrutiny. The purpose of intestacy statutes is to label as family, and therefore takers, some list of people at the expense of others. That is what intestacy statutes do: they define family. Then, intestacy statutes discriminate-on purpose-between family members.").

117 Thompson v. Coates, 627 S.W.2d 376, 381 (Tenn. Ct. App. 1981); TenN. Code ANN. § 31-2105 (1981) ("Parent and child relationship: 'for purposes of intestate succession, person is a child of the father the paternity is established by an adjudication before the death of the father or is established thereafter by clear and convincing proof."')

118 TENN. CODE ANN. § 31-2-105 (1981).

119 Thompson, 627 S.W.2d at 376. 
"finally vested" upon the death of the decedent. ${ }^{120}$ This was a due process argument for the defendants' property interest, much like the court in Rose acknowledged and held in favor of. ${ }^{121}$

The court in Tennessee differed from the Third District in Rose, correctly noting that while the defendant in Thompson had a valid property interest, it was not "finally vested." 122 The Court of Appeal found this lack of a finally-vested property interest to be evidenced by the fact that "upon the death of a decedent [there] is the authority given the representative of an estate to utilize the real property to discharge decedent's obligations." ${ }^{23}$ In other words, the property interest is not finally or fully vested until the probate administration is completed. The estate's property is subject to claims of creditors, allowable expenses of the decedent, pretermitted spouse and pretermitted child claims, claims for an elective share, will contests, and other similar matters. Until all these issues are resolved, no property interest is truly, fully vested. This delay in the final vesting of the rights of inheritance in the other heirs of the decedent is consistent with the delay prompted by the filing of claims by actual creditors, those seeking to assert or contest a will, etcetera. ${ }^{124}$

If one compares the reasoning of the Court of Appeal in Tennessee in Thompson, to hold in favor of the child born out of wedlock, with the reasoning of the Third District Court of Appeal in Florida in Rose, to hold against the child born out of wedlock, the Tennessee explanation is more logical and equitable. While it is true that Sonson's estate, personal representative, and legitimate children had an interest in the property, so too did Rose in claiming the property as the alleged heir of his father. ${ }^{125}$ To rely on the restrictive, and possibly unconstitutional, statute of limitations in cases like this "would effectively bar illegitimate children from establishing paternity after the death of the father."126

Such a result would be in contravention to the unambiguous effect of the statute and inequitable where the opposing property interest would still be subject to other claims, such as creditors. If the Florida Supreme Court and the legislature adopt the view that no rights are fully vested until probate proceedings are closed, then there would seem to be no constitutional problem posed by allowing the Florida Legislature to amend section

$120 \quad$ Id. at 381.

121 Rose v. Sonson, 208 So. 3d 136 (Fla. Dist. Ct. App. 2016), reh'g denied (Oct. 18, 2016), review denied, SC16-2083, 2017 WL 1954982 (Fla. May 11, 2017).

122 Thompson, 627 S.W.2d at 38.

123 Id.

124 Glanton v. Lord, 183 S.W.3d 391, 399 (Tenn. Ct. App. 2005).

125 Rose, 208 So. 3d at 136.

126 Thompson v. Coates, 627 S.W.2d 376, 381 (Tenn. Ct. App. 1981). 
732.108(2)(b) of the Florida Statutes once more to expressly provide for retrospective application of the 2009 amendment.

The Third District's holding that "any such retroactive application would constitute a violation of the decedent's and of the co-personal representatives' due process rights because Rose's claim was already extinguished" 127 is wrong because the decedent and co-representative did not have vested property rights, and still had the opportunity to defend their claims from the alleged heir in probate proceedings. If anyone's due process rights would be infringed by not allowing the 2009 amendment to be retroactive, it would be the illegitimate child because strictly prospective application would "effectively bar illegitimate children from establishing paternity after the death of the father."128

\section{B. Reverse to Revive-Goodbye In re Estate of Smith}

Even if one were to accept that "retroactive application would constitute a violation of the decedent's and of the co-personal representatives' due process rights because Rose's claim was already extinguished," ${ }^{129}$ and that the legislature could not make the 2009 amendment retroactive, the Florida Supreme Court may have a judicial lane around this legislative limitationoverruling precedent. The four-year statute of limitations does not expressly apply to paternity claims for intestate succession after the death of the putative father. ${ }^{130}$ Instead, the limitation was imposed upon the claimant (and future claimants) by the Florida Supreme Court in In re Estate of Smith ${ }^{131}$ If the Court renounces its decision in Smith and adopts a new view, then that holding, rather than the statute, could apply retroactively.

There is at least one similar example of a limitation being ruled unconstitutional such that a holding was then applied retroactively. ${ }^{132}$ In Black v. Nesmith, a married mother filed a complaint to determine paternity against the father, who was not the husband. ${ }^{133}$ The father moved to dismiss because the controlling statute when the child was born only allowed for the

127 Rose v. Sonson, 208 So. 3d 136 (Fla. Dist. Ct. App. 2016), reh'g denied (Oct. 18, 2016), review denied, SC16-2083, 2017 WL 1954982 (Fla. May 11, 2017).

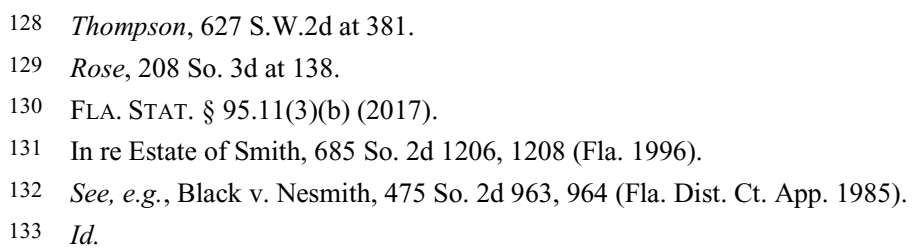


complainant to be unmarried, and the mother was married. ${ }^{134}$ Although the statute was later amended (prior to the mother's action) to eliminate the term "unmarried," the father argued that retroactive application of the amendment to permit the suit against him would be unconstitutional because his property rights were vested under the previous statute's limitations. ${ }^{135}$ The court disagreed, noting that although the Florida Legislature did not make an express intention of retroactivity, "[t]he general rule regarding retroactivity of a decision of a court of last resort overruling a decision is that such a decision is retrospective as well as prospective in its operation unless declared by the opinion to have a prospective effect only." 136

Because the limitation imposed by the word "unmarried" was deemed unconstitutional in a previous case, Gammon v. Cobb, the Court in Black concluded that the Gammon holding could be applied retroactively even though the legislative amendment removing the requirement that a claimant not be married was not expressly retroactive. ${ }^{137}$ Further, the Court noted that "[s]ection 742.011 is intended solely to protect the rights of illegitimate children and to insure that all children are supported by their natural fathers ... Given this policy, we find it unlikely that the Legislature intended to create a right in defendants to avoid their obligations" by using the limitations imposed within the statute to their advantage. ${ }^{138}$ The married mother in Black could maintain her paternity action against the father based on the retroactivity of Gammon, even though at time of the child's birth the statute limited such actions to unmarried women. ${ }^{139}$

Applying Black to section 732.108(2)(b) of the Florida Statutes, a similar result can be reached if the Florida Supreme Court elects to overrule its 1996 decision of In re Estate of Smith, and adopts the First District Court of Appeal's decision instead. ${ }^{140}$ While the amendment to section $732.108(2)$ (b) does not expressly state an intention to make the new rule retroactive, the legislative history of the amendment sheds light upon the

134 "Any unmarried woman who shall be pregnant or delivered of a child may bring proceedings in the circuit court, in chancery, to determine the paternity of such child." Id. (quoting FLA. STAT. $\S$ $742.011(1969))$.

135 Black, 475 So. 2 d at 965.

136 Id. at 964 (citing Dep't of Revenue v. Anderson, 389 So. 2d 1034 (Fla. Dist. Ct. App. 1980)); Int'1 Studio Apartment Ass'n, Inc. v. Lockwood, 421 So. 2d 1119 (Fla. Dist. Ct. App. 1982).

137 Id. at 964 (citing Gammon v. Cobb, 335 So. 2d 261 (Fla. 1976)).

138 Black, 475 So. 2d at 964.

139 Id.

140 In re Estate of Smith, 640 So. 2d 1152, 1153 (Fla. Dist. Ct. App. 1994), approved in part and remanded sub nom.; In re Estate of Charles W. Smith; Dale S. Wilson v. Shirley I. Scruggs; Dale S. Wilson v. Shirley I. Scruggs, No. 84,385, 1995 WL 689549 (Fla. Nov. 22, 1995), opinion withdrawn and superseded on reh'g sub nom. In re Estate of Smith, 685 So. 2d 1206 (Fla. 1996), and decision quashed, 685 So. 2d 1206 (Fla. 1996). 
legislature's intent. Per the Florida Staff Analysis, reviewing the amendment, "[t]his bill overrules the holding in Estate v. Smith [same as In re Estate of Smith] and provides that ch. 95, F.S., does not apply in determining heirs in a probate proceeding." 141

The amendment did not say that section 95.11(3)(b) no longer applies in determining heirs in a probate proceeding. ${ }^{142}$ Instead, it states that the statute does not apply. ${ }^{143}$ Such universal language independent from timing of the claim, coupled with the express intention to overrule In re Estate of Smith, indicates that the legislature believed the holding of the First District Court of Appeal of Florida correctly decided In re Estate of Smith - not the Supreme Court holding that later quashed the First District. ${ }^{144}$ Therefore, this showing of legislative intent opens up the opportunity for the Florida Supreme Court to reverse its holding and adopt the opinion of the First District, something the Third District failed to acknowledge in Rose $v$. Sonson.

In its 1994 opinion, the First District Court of Appeal held in In re Estate of Smith that the statute of limitations applicable to paternity proceedings to establish support does not apply to actions to establish paternity for purposes of intestacy. ${ }^{145}$ The court found multiple constitutional violations in that case, holding that the application of section 95.11(3)(b) would (1) allow preemption of a claim which never accrued, in violation of the state constitution and intestate succession statutes; and (2) would treat similarly situated illegitimate children, and similarly situated legitimate and illegitimate children, disparately. ${ }^{146}$

First, the First District was correct in holding that applying section 95.11(3)(b) would allow preemption of a claim which never accrued, in violation of the Florida Constitution and intestate succession statutes. ${ }^{147}$ Per section 732.101(2) of the Florida Statutes, "[t]he decedent's death is the event that vests the heirs' right to the decedent's intestate property." 148 Simple logic shows that application of the four-year statute of limitations beginning from the age of majority allows a claim to be barred before it ever accrued. Chapter 95 , which houses the statute of limitations, also states that "the time within

141 H.B. 599, 2009 H.R. Reg. Sess. (Fla. 2009) (emphasis added).

142 Id.

143 Id.

144 Smith, 640 So. 2d at 1155.

145 See generally id.

146 Id. at $1154-56$.

147 Id. at 1155.

148 FLA. STAT. $§ 732.101(2)$ (2017). 
which an action shall be begun under any statute of limitations runs from the time the cause of action accrues." 149

By barring the claim before it accrued, the First District held, the plaintiff's constitutional right of access to the courts was violated. ${ }^{150}$ The statute of limitations was truly a statute of repose, allowing for discriminatory results whenever illegitimate children were unable to discover the identities of their fathers, or bring suit, before the age of twenty-two. As the Court noted in Black that section 742.011 is "intended solely to protect the rights of illegitimate children," it should apply the same understanding to section $732.108(2)(b) .{ }^{151}$ Under the umbrella of such a policy, it is "unlikely that the Legislature intended to create a right in defendants to avoid their obligations" by using the limitations imposed within the statute to their advantage. ${ }^{152}$

Also, the Court was correct in holding that application of the four-year statute of limitations would treat similarly situated illegitimate children and legitimate children, disparately. ${ }^{153}$ In its analysis the Court looked to a 1975 case, State, Department of Health and Rehabilitative Services v. West, ${ }^{154}$ which held the same statute of limitations unconstitutional as it related to claims for support. ${ }^{155}$ There, the Court balanced the state's objective to avoid stale claims against the impact of the statute upon illegitimates deprived of their right to support. ${ }^{156}$ The First District in Smith noted that the holding in West, striking the statute on equal protection grounds, was instructive to its analysis. ${ }^{157}$

"Although proof of paternity may become more difficult with the passage of time, this mere possibility cannot be allowed to work an unconstitutional discrimination against illegitimate children." ${ }^{158}$ Like West, it should be unconstitutional under the Equal Protection Clause to allow legitimate offspring to have a claim accrue at the death of the father, while forcing a child born out of wedlock to surrender such a claim before it ever accrues. Further, in Black, the court discussed West and noted its

149 FLA. STAT. $§ 95.11(3)(\mathrm{b})$ (2017).

150 Smith, 640 So. 2d at 1155.

151 Black v. Nesmith, 475 So. 2d 963, 965 (Fla. Dist. Ct. App. 1985).

152 Id.

153 "As applied below, the statute also treats similarly situated illegitimate children with disparity - for the child whose father dies during the child's minority, the right to seek inheritance is always preserved; for the child who is twenty-two or older at her father's death, the right would never be preserved.” In re Estate of Smith, 640 So. 2d 1152, 1156 (Fla. Dist. Ct. App. 1994).

154 State, Department of Health and Rehabilitative Services v. West, 378 So. 2d 1220, 1222 (Fla. 1979).

155 Smith, 640 So. 2d at 1155.

156 Id.

157 Id.

158 Id. 
acquiescence to the fact that "[t]his holding operated to deprive West of a defense which had clearly existed at the child's birth." 159 Florida must accept the premise that "illegitimate children are not 'nonpersons.' They are humans, live, and have their being. They are clearly 'persons' within the meaning of the Equal Protection Clause of the Fourteenth Amendment." 160

West and Black illustrate that an unconstitutional application of section 95.11(3)(b) to bar a paternity complaint can be overcome despite the defense the limitation provided the father, whether being applied to section 742.011 in West, or section 732.108(2)(b) in Rose, and future paternity actions brought in probate proceedings. ${ }^{161}$ Therefore, if the Florida Supreme Court overrules its decision In re Estate of Smith, and adopts the lower court's holding that section 95.11(3)(b)'s four-year statute of limitations was unconstitutional, it cannot be said that all claims expired under that statute are truly extinguished. Of course, retroactive application of a Supreme Court holding would need some limitation to protect the state's valid interest in avoiding stale claims, finality in final dispositions, and the orderly descent of property. Such interests are not present for claimants such as Rose, where the probate case is still happening and the claimant is imposing no additional burden upon the state, court or estate of the decedent than any common creditor would be. Retroactive application of a Supreme Court decision to overrule In re Estate of Smith would be more than appropriate- it would be equitable.

If the Supreme Court were to take up a case involving $732.108(b)(2)^{162}$, the Court would accept that section 95.11(3)(b) never applied to determining heirs in a probate proceeding for intestate inheritance. Such a holding would allow claimants like Rose, and other similarly situated children born out of wedlock, to assert their constitutional right of access to the courts by petitioning their claims for intestate inheritance as putative children of the deceased. In fact, the four-year statute of limitations can be considered unconstitutional just as former section 731.29, which required written acknowledgment of paternity by the father of the illegitimate child in order for that child to inherit from the father via intestate succession, and violated an illegitimate child's right to equal protection. ${ }^{163}$ Just as that statute was discrimination veiled beneath a "standard of proof" justification in In re

159 Black v. Nesmith, 475 So. 2d 963, 965 (Fla. Dist. Ct. App. 1985).

160 State, Department of Health and Rehabilitative Services v. West, 378 So. 2d 1220, 1222 (Fla. 1979) (quoting Levy v. Louisiana, 391 U.S. 68, 70 (1968)).

161 See generally Black, 475 So. 2d at 965.

162 The Court denied review of Rose v. Sonson on May 11, 2017.

163 In re Burris Estate, 361 So. 2d 152, 154 (Fla. 1978). 
Burris Estate, the four-year statute of limitations as applied to section $732.108(b)(2)$ is discrimination veiled beneath a stale claim justification. ${ }^{164}$

For example, imagine a girl born out of wedlock has a close relationship with her putative father. ${ }^{165}$ The girl lives at least part time with the father and grows up in the same home as her half brothers and sisters. For whatever reason, the father never adopts the child, marries the mother, or acknowledges the paternity in writing. ${ }^{166}$ She grows up, reaches majority, goes to college, and makes a life. Her father becomes the grandfather of her children, the father-in-law to her husband, etcetera. Eventually, the father dies, without a will, so that his estate is to pass through intestate succession. No doubt that because the daughter grew up with her father's other children, and she maintained an open relationship with him throughout her life, the other children and any other interested parties to the estate were on notice that the girl was the daughter of the deceased and would make a claim on his estate. In this instance, the "stale claim" justification of the four-year statute of limitations from the time the daughter turned eighteen would simply be a veil for discrimination against the daughter because the limitation would operate just the same, whether the other interested parties were on notice or not.

If a legitimate heir may claim inheritance in a probate proceeding, there is no reason for a putative father's estate to be shielded by an unconstitutional statute of limitations from an illegitimate heir's equally valid claim. Like In re Burris Estate, such a statute does not serve the state's interest asserted in Rose (avoiding stale claims or the due process rights of the defendants), but instead creates an "impenetrable barrier that works to shield invidious discrimination." ${ }^{167}$ By overruling In re Estate of Smith and adopting the First District Court of Appeal's opinion, the Florida Supreme Court would be applying the statute retroactively by noting the unconstitutionality of the previous statute. The result would be that the claims were not extinguished because the statute was void as applied to paternity claims in probate proceedings for the purposes of intestate succession.

\section{Provide A New Claim in Lieu of Reviving the Old One}

As with any evolving area of the law, the arguments above are not certain to succeed. The Florida Supreme Court is not as predictable as Jon

$164 I d$. at 155.

165 "More than $50 \%$ of all nonmarital children today are born to cohabiting couples." Solangel Maldonado, Illegitimate Harm: Law, Stigma, and Discrimination Against Nonmarital Children, 63 FLA. L. REV. 345, 356-57 (2011).

166 The ways paternity can be established under FLA. STAT. § 732.108(2) (2017).

167 Burris, 361 So. $2 \mathrm{~d}$ at 155. 
Snow's vengeance, ${ }^{168}$ and it is wholly possible that the Court will decide not to overrule In re Estate of Smith. The Court may distinguish Smith from a case like Gammon v. Cobb or Blackv. Nesmith and hold that even overruling Smith would not have the same retroactive effect as those cases contemplated. Also, if the Legislature acts to make the 2009 amendment retroactive, the Court might hold the retroactive application unconstitutional, sticking with the reasoning of Third District Court of Appeal's opinion in Rose. ${ }^{169}$

While such a decision would be wrong, it is not wholly out of the purview of valid legal argument. Therefore, there is an alternative route that could circumvent any roadblocks the Supreme Court could erect-amend section 732.108(2)(b) to provide a new cause of action. Provide rather than revive. If there is a political will to do so, the Florida Legislature could provide for a new cause of action that would allow claimants currently barred by the now inapplicable statute of limitations to once again assert their constitutional right of access to the courts.

The First District Court of Appeal, perhaps by accident, has provided a potential title to the new cause of action in its quashed opinion in In re Estate of Smith - "The Action to Inherit." "For the sake of clarity, the title to the amendment could be "The Action for Children Born out of Wedlock to Inherit." The proposed amendment should be entered as a subsection to section 732.108(2)(b). The amended statute could read as follows, with the added language in italics:

732.108. Adopted persons and persons born out of wedlock

(2) For the purpose of intestate succession in cases not covered by subsection (1) ... The person is also a descendant of his or her father and is one of the natural kindred of all members of the father's family, if:

(b) The paternity of the father is established by an adjudication before or after the death of the father. Chapter 95 shall not apply in determining heirs in a probate proceeding under this paragraph.

(A) Establishing paternity for the purpose of intestate succession shall be a distinct cause of action from

168 Spoiler alert, most of Jon's family is murdered throughout Game of Thrones, and a group of disloyal men turn on him.

169 Rose v. Sonson, 208 So. 3d 136 (Fla. Dist. Ct. App. 2016), reh'g denied (Oct. 18, 2016), review denied, SC16-2083, 2017 WL 1954982 (Fla. May 11, 2017). The Supreme Court denied review without addressing the issue in May 2017.

170 "The action to inherit is a distinct statutory cause of action, not within the contemplation of the bar imposed by Section 95.11(3)(b)." In re Estate of Smith, 640 So. 2d 1152, 1154 (Fla. Dist. Ct. App. 1994) (emphasis added), aff'd, in part, rev'd, in part; see also In re Estate of Charles W. Smith; Dale S. Wilson v. Shirley I. Scruggs; Dale S. Wilson, No. 84,385, 1995 WL 689549 (Fla. Nov. 22, 1995), opinion withdrawn and superseded on reh'g sub nom. In re Estate of Smith, 685 So. 2d 1206 (Fla. 1996). 
establishing paternity under section 742.10. This distinct cause of action shall be known as The Action for Children Born out of Wedlock to Inherit. However, if paternity is established under section 742.10, then the right to inherit is established, and the action established by this subsection need not be brought.

(i) The Action for Children Born out of Wedlock to Inherit shall accrue at the time of the putative father's death. Notice of administration shall be published, and any child born out of wedlock asserting a claim established by this subsection shall assert their claim within the same time allowed to a legitimate child to bring his/her claim for intestate inheritance as an heir.

(ii) This section shall not be construed to create a cause of action where an estate has been fully administered and probate proceedings have been closed.

By creating this new cause of action, the Legislature can avoid any constitutional issues that could arise from making the 2009 amendment retroactive and can quickly provide a remedy to Rose and other similarly situated Florida citizens, rather than wait for the Supreme Court to address the issue. There are two issues that would need to be addressed with this new amendment: (1) what statute of limitations, or time limit, if any, should apply to this new cause of action; and (2) how should this new cause of action affect children born out of wedlock who reached the age of majority before their father died, when section 95.11(3)(b) was applicable, and the probate proceedings have since been completed.

The answer to the second question is simple: the state's interest in finality and the orderly descent of property is too strong to justify opening a closed probate administration. If this limitation were not imposed, the courts would be overrun with alleged heirs reopening probate administrations and unsettling vested property interests. Such a result cannot be supported. Rather, the intended purpose of the proposed amendment is to allow a claimant to assert his or her status as child born out of wedlock when the claimant would be imposing no additional burden upon the state, court, or estate of the decedent than any other heir would be. Quite simply, this proposed amendment would extend the application of the 2009 amendment to section $732.108(2)(b)$ to the additional parties that the legislature contemplated when it expressed its intention to overrule In re Estate of Smith in its Staff Analysis. ${ }^{171}$ 
The possible answers to the first question may be found in the statutes and policies of other jurisdictions with similar statutes. With a goal of adding no additional time burden to the administration process, one may analyze the time limits imposed in Tennessee and New York. These states were chosen because of the similarity their out of wedlock inheritance statutes hold with section 732.108(3)(2) of the Florida Statutes, and because of their success in achieving the intended goal of the amendment proposed above.

\section{Comparative Analysis: Wisdom of Other States May Fill Florida's Legal Void}

While the amendment to section 732.108(2)(b) is a step in the right direction, its inability to provide a remedy for individuals like Stephen Rose, coupled with its lack of clarity regarding the statute of limitations to apply in paternity adjudication claims for intestate succession in the future, causes a gap in the law that must be filled. Researching other states, Tennessee and New York emerged to contain two of the statutory schemes most favorable to individuals such as Rose, balancing the state's interest in the orderly descent of property of its citizens, and the right for children born out of wedlock to inherit like any other child.

\section{Tennessee}

Tennessee's out of wedlock inheritance laws are similar to Florida's, but the statute of limitations is not. ${ }^{172}$ Under Tennessee law, "for purposes of intestate succession, a relationship of parent and child must be established to determine succession by ... an adjudication before the death of the father or ... thereafter by clear and convincing proof." 173 Tennessee allows a paternity claim to be brought up until a creditor claim can be brought, essentially treating illegitimate children and creditors with the same status for purposes of timeliness of claims. ${ }^{174}$ Previously, Tennessee had a ten-year statute of

172 See Lanier v. Rains, 229 S.W.3d 656, 662 (Tenn. 2007).

173 TENN. CODE ANN. § 31-2-105 (2017).

174 Bilbrey v. Smithers, 937 S.W.2d 803, 808 (Tenn. 1996) (“[A] child born out of wedlock, whose paternity is not adjudicated prior to the death of the father, can establish the right to inherit by intestate succession by asserting that right against the estate of the deceased owner of the property in which an interest is claimed within the time allowed for creditors to file claims against the estate and by establishing paternity by clear and convincing proof."); see also TENN. CODE ANN. § 31-2-105(a)(2)(B) (2017); "If a child born out of wedlock asserts his status as a child of a decedent and a corresponding right to inherit by intestate succession within the time allowed for creditors to file claims against the decedent's estate, the claim will not be barred by any statutory limitations period." Lanier, 229 S.W.3d at 662 . 
limitations, which could run prior to the death of the father. ${ }^{175}$ However, the court said in Thompson $v$. Coates that the statute of limitations would not apply because if the ten-year period ran before the father's death, the child would be barred from bringing suit to establish his share of the estate, even though the statute specifically allows suit to be brought after the death of the father. ${ }^{176}$

Section 732.108(2)(b) of the Florida Statutes also clearly established that the paternity of the father may be established "by an adjudication before or after the death of the father." ${ }^{177}$ Using the same reasoning as Thompson, one finds that allowing the alleged heir's claim to extinguish before the father's death is in contravention to Florida's policy of allowing children to prove paternity for the purpose of intestate succession after the father's death. Florida should consider a policy like Tennessee's for several reasons. Such a standard provides a well-defined rule, notice to claimants, guarantees an opportunity to prove paternity after death, protects the rights of creditors and future owners of the estate's property, and creates no additional restrictions on rights of inheritance than what already exists (such as creditors, taxing authorities, and legitimate children). ${ }^{178}$ Although the creditor time limit may seem arbitrary, the Court in Tennessee was able to justify this decision:

While conceding that its decision was "somewhat arbitrary," the Court explained that it chose this limitations period because (1) it could be implemented by reference to familiar and well defined rules, (2) it provided the constitutionally mandated notice to claimants, (3) it protected the rights of creditors and subsequent property owners, (4) it posed no threat to "rights of inheritance" beyond those already posed by creditors and taxing authorities, and (5) it retained the current degree of dependability in the titles to intestate property. ${ }^{179}$

In Glanton v. Lord, cousins filed separate actions seeking sale and partition of real property previously owned by their deceased uncle and grandfather, and determination of inheritance rights of the decedents' putative heirs. ${ }^{180}$ The cousins argued, inter alia, that because their uncle had been dead for forty years, and the putative children had not made their claim

175 TenN. CodE ANN. $\S \S$ 28-3-110, 31-206; see Thompson v. Coates, 627 S.W.2d 376, 380 (Tenn. Ct. App. 1981).

176 Thompson, 627 S.W.2d at 380.

177 FLA. STAT. $§ 732.108$ (2)(b) (2017) (emphasis added).

178 Bilbrey, 937 S.W.2d at 808.

179 Glanton v. Lord, 183 S.W.3d 391, 396 (Tenn. Ct. App. 2005).

180 Id. at 394. 
within the ten-year catch-all statute of limitations, they were barred from claiming inheritance. ${ }^{181}$ The Court of Appeals of Tennessee disagreed, holding that even if the statute of limitations applied to claims for inheritance by children born out of wedlock, "[t]he statutes of limitation applicable to creditors' claims - and thus to a non-marital child's claim of paternity and a corresponding right to inherit by intestate succession - does not begin to run until after a decedent's estate is submitted to probate and a statutory Notice to Creditors is published." 182 Because the decedent's estate was never submitted to probate, the limitations period had not begun to run, and the claim of the putative children was timely. ${ }^{183}$

Florida should adopt the same understanding of its statute defining the rights of children born out of wedlock to inherit through intestate succession. The rights of potential heirs should not vest until after certain conditions are met, including the satisfaction of valid claims of creditors. Providing children born out of wedlock the same access to intestate succession puts no additional time burden on other parties interested in the administration of the estate. Therefore, allowing the right to assert a claim for inheritance through paternity to expire prior to the death of the putative father, or before the probate administration has been opened, would be in contravention of the statutory purpose indicated by the Florida Legislature and Supreme Court, as was held in Tennessee. ${ }^{184}$

\section{New York}

New York is also very forgiving, removing time limits for bringing the inheritance claim, but including limitation on which children born out of wedlock have standing to bring the claim. ${ }^{185}$ Although the statute defining the right of nonmarital children to inherit from their fathers is somewhat different than Florida's section 732.108(2)(b), its application by the courts is telling of how the policy of the statute is important in the interpretation of the

\footnotetext{
181 Id.

182 Id. at 400.

183 Id. at 398.

184 Thus, the imposition of such a requirement would, in many cases, essentially undermine the statutory command that non-marital children be allowed to inherit by intestate succession from or through their biological father if paternity is established by an adjudication before the father's death "or is established thereafter by clear and convincing proof."
}

TENN. CodE ANN. § 31-2-105(a)(2)(B). We do not believe the Tennessee Supreme Court intended such a result with its decision in Bilbrey v. Smithers.

Glanton, 183 S.W.3d at 399 (emphasis added).

185 N.Y. Est. Powers \& Trusts Law $\S 4-1.2$. 
statute. ${ }^{186}$ In New York, "[t]here is no time limitation for the establishment of paternity." 187

If a non-marital child discovers belatedly that her father has died, she can seek an accounting if the statute of limitations has not run. ${ }^{188}$ The statute of limitations begins to run when the fiduciary openly repudiates his fiduciary obligations. ${ }^{189}$ However, not every non-marital child in New York can assert their claim of paternity for purposes of intestate succession: "The language of Section 4-1.2(a)(2)(C) states that a nonmarital child can inherit from a biological father's estate if 'paternity has been established by clear and convincing evidence and the father of the child has openly and notoriously acknowledged the child as his own." 190 Thus, in New York, a nonmarital child cannot become an heir to the estate of the putative father the child did not know. ${ }^{191}$

Originally, New York case law said that "genetic testing must be administered during a putative father's lifetime for the results to be admissible to establish paternity in an heirship proceeding." 192 However, in 2006, the court in In re Davis said that genetic testing to prove paternity after death was allowed so long as there was an open and notorious acknowledgement of paternity. ${ }^{193}$

Florida policy makers, if they so choose, could limit the potential pool of children born out of wedlock who could inherit through intestacy, like New York. Instead of an arbitrary cutoff date calculated from the age of majority, or even the age of death, such a rule as New York has is rationally related to the intended purpose of the orderly descent of its citizens' property. By limiting the pool of possible claimants to those children who were at least acknowledged by the father during life, other interested parties are placed on notice, and the time for administration need not be unduly delayed while claims of putative children are found and argued. Although this author does

186 See Matter of Williams, 609 N.Y.S.2d 643 (N.Y. App. Div. 1994) (refusing to allow the doctrine of laches to be asserted as a defense against claim to be included as distribute under this section).

187 N.Y. EST. POWERS \& TRUSTS LAW § 4-1.2 (Practice Commentaries).

188 See Matter of Barabash, 286 N.Y.2d 268, 269-70, 272 (1972) (decedent's issue entitled to accounting twenty years after his death because administrator had not repudiated his fiduciary duties); In re Estates of Cipriani, 889 N.Y.S.2d 881, *2 (Sur. 2009) (non-marital child learned of her father's death ten years after he had died; and court ordered accounting).

189 See Cipriani, 889 N.Y.S.2d at *4.

190 Pandelton, supra note 88, at 2856; see also N.Y. EST. POWERS \& TRUST LAW $\S 4-1.2(\mathrm{a})(2)(\mathrm{C})$ (McKinney 2010 (2007)).

191 Pandelton, supra note 88 , at 2856.

192 Id. at 2855.

193 In re Davis, 812 N.Y.S.2d 543, 547 (N.Y. App. Div. 2006). 
not see a need for a limitation such as New York has implemented, there is no arguing against its pragmatism. ${ }^{194}$

\section{CONCLUSION}

Like fictional fifteenth century Jon Snow, children born out of wedlock in the twenty-first century continue to face laws that discriminate against them for decisions they played no part in. Florida's Third District Court of Appeal's holding in Rose v. Sonson creates an inequitable result for children born out of wedlock, now twenty-nine years or older, who seek to establish paternity for the purpose of intestate succession after their fathers pass away. ${ }^{195}$ By ignoring the Legislature's intention, as expressed by its Staff Analysis, to overrule the decision of In re Estate of Smith, the court allowed an unconstitutional statute of limitations to continue to apply to a substantial portion of Florida's population. ${ }^{196}$ Smith incorrectly applied section 95.11(3)(b) to section 732.108(2)(b) so that a child born out of wedlock only had four years from the age of majority to assert a paternity claim. ${ }^{197}$ If the child waited until the death of the putative father, more than four years after attaining the age of majority, to bring the claim, then the child was barred from bringing his or her claim. This decision in Smith was in contravention of the express language of section 732.108(2)(b) that says the claim for paternity can be brought after death with clear and convincing evidence. ${ }^{198}$ Although the Florida Legislature finally acted in 2009 to fix this conflict

194 Id. at 546-47 (quoting Lalli v. Lalli, 439 U.S. 259, 271 (1978)) ("With respect to the rights of nonmarital children, the State has an interest in minimizing the potential for disruption of estate administration' ... which would not be served by indiscriminate posthumous DNA testing. Although technical advances in genetic testing have obviated difficulties in proving paternity and rendered such proof reliable and accurate in most cases, procedural difficulties remain. In the absence of an open and notorious acknowledgment of paternity by the decedent, persons unknown to the decedent and/or his or her personal representative potentially could have rights in an estate.").

195 Rose v. Sonson, 208 So. 3d 136 (Fla. Dist. Ct. App. 2016), reh'g denied (Oct. 18, 2016), review denied, SC16-2083, 2017 WL 1954982 (Fla. May 11, 2017).

196 This bill overrules the holding in In re Estate v. Smith and provides that ch. 95, F.S., does not apply in determining heirs in a probate proceeding. Therefore, this bill allows for a determination of paternity to be made in a probate proceeding for the purpose of proving heirship, even if it is more than four years after the date the child reaches majority. This change is limited to intestate succession.

Fla. H.R. Comm. on Civil Justice \& Courts Policy, StafF Analysis of HB 599, at 3 (2009).

197 See In re Estate of Smith, 685 So. 2d 1206, 1208 (Fla. 1996); (“Actions other than for recovery of real property shall be commenced as follows: . . . (3) Within four years._. . . (b) An action relating to the determination of paternity, with the time running from the date the child reaches the age of majority.") FLA. STAT. § 95.11(3)(b) (2017).

198 FLA. STAT. $\S 732.108(2)(b)$ (2017). 
between precedent and policy, the amendment was not applied retroactively. ${ }^{199}$

If the legislature can legally act to expressly make the statute retroactive, it should. However, it may be impossible to affect a result other than what Rose implies - that anyone twenty-nine years old or older in 2016 is barred from paternity claims in probate court, because of the possibility that retroactive application is not allowed due to its effect on the rights of decedents' estates and representatives to protect their property interests with the statute of limitation. ${ }^{200}$ Although there are cases interpreting other statutes (and similar statutes in other jurisdictions), showing that the statute of limitation has not created a fully vested right in other interested parties, such as heirs, and that the rights of those negatively affected by the change in the statute of limitations are not as strong as those who are losing their claim because of the limitation, ${ }^{201}$ the Court has not adopted that view for cases under section 732.108(2)(b). For now, Florida would likely see this as a violation of due process for the party losing the statute of limitations as a defense, rather than a violation of due process and equal protection by extinguishing a nonmarital child's claim before it accrued, or treating the nonmarital child differently than similarly situated legitimate children. ${ }^{202}$

If the Legislature cannot make the statute retroactive, the Florida Supreme Court may choose to overrule In re Estate of Smith. While the Court cannot make the amendment retroactive without an express intent to do so by the legislature, it can look to the legislative history of the amendment to see an intention to overrule Smith - the seminal case applying the four-year statute of limitations on adjudications of paternity in probate proceedings for intestate succession. By heeding the legislature's intention and revisiting Smith, the Court can overrule the decision and adopt the lower court's holding that application of the limitation would be unconstitutional by infringing on the right to access to the courts and equal protection by preempting a claim which has not accrued, and treating children born out of wedlock differently from legitimate children without proper justification. With the precedent of Smith reversed, the 2009 amendment will apply retroactively, in a sense, by allowing claimants such as Rose to bring their claims. However, the state's interest would still be served because the amendment would not revive claims on estates that have already been fully administered.

199 Id

200 See generally Rose v. Sonson, 208 So. 3d 136 (Fla. Dist. Ct. App. 2016), reh'g denied (Oct. 18, 2016), review denied, SC16-2083, 2017 WL 1954982 (Fla. May 11, 2017).

201 See, e.g., Black v. Nesmith, 475 So. 2d 963, 965 (Fla. Dist. Ct. App. 1985).

202 See generally In re Estate of Smith, 685 So. 2d 1206 (Fla. 1996). 
If the Legislature cannot make the amendment retroactive, and the Supreme Court will not overrule precedent that applied the statute of limitations in the first place, then the Legislature could choose to supply a new claim-The Action for Children Born out of Wedlock to Inherit. By providing a new claim, the Legislature would be able to act quickly instead of waiting for the Supreme Court to take up the issue (if it ever does) and avoid the potential unconstitutionality of an amendment for retroactive application. The amendment would not apply to nonmarital children whose fathers' estates have already been administered and closed before the enactment of the amendment, thus protecting the state's interest in finality, avoiding stale claims, and protecting vested property interests.

The proposed amendment would have to address the issue of what time frame, if any, should apply to the new cause of action. Based on analysis of states with intestacy and out of wedlock statutes that effectively meet the goal of adding no additional time burden to the administration process while protecting the interests of children born out of wedlock, Tennessee and New York each supply guidance for what time limitations should be imposed on this new cause of action. Ultimately, the applicable time limitation should provide a well-defined rule, notice to claimants, guarantee an opportunity to prove paternity after death, protect the rights of creditors and future owners of the estate's property, and create no additional restrictions on rights of inheritance than what already exist (such as creditors, taxing authorities, and legitimate children). Tennessee's system does best to achieve these goals by forcing nonmarital children to bring a claim within the time allowed for creditors to file claims against the decedent's estate. ${ }^{203}$

However Florida chooses to proceed, policy makers and the judiciary must recognize the history of discrimination against children born out of wedlock-from Jon Snow to Stephen Rose. Equal protection and due process must be afforded to nonmarital children, who should not suffer for the socalled sins of their fathers. The time has come to end disproportionate treatment toward out of wedlock children in Florida's probate system. 